\title{
Cognitive style in anorexia nervosa: a preliminary investigation
}

\author{
Natalie Crino ${ }^{1 *}$, Stephen Touyz ${ }^{2}$ \\ From 2015 ANZAED Conference: Riding the Waves to Recovery \\ Surfers Paradise, Australia. 21-22 August 2015
}

Considerable research has been devoted to examining the content of cognition in eating disorders, which typically includes dysfunctional thoughts, attitudes and underlying assumptions about the importance of controlling eating, shape and weight. Far less is known about the style of cognition. An unhelpful cognitive style might include perseverative forms of thought (Nolen-Hoeksema, Parker \& Larson, 1994); problemoriented coping (Carver, Scheier \& Weintraub, 1989); the tendency to become over-involved or "fused" with cognition (Hayes, Luoma, Bond, Masuda, \& Lillis, 2006); and having a self-blaming attributional style (Anderson, Miller, Riger \& Sedikides, 1994). The aim of the current study was to examine the extent to which aspects of cognitive style are associated with symptoms and features of anorexia nervosa. Participants from a specialist eating disorder clinic completed self-report questionnaires examining cognitive content, cognitive style, and symptoms. Preliminary findings demonstrate strong inverse relationships between eating disorder symptoms and reappraisal, problem-oriented coping, and cognitive defusion in particular. These results highlight the need to further investigate the role of cognitive style in anorexia nervosa. This aspect of cognition might help to explain why cognitive pathology tends to persist even in those who have recovered.

\section{Authors' details}

'Department of Medical Psychology, Westmead Hospital, Sydney, Australia.

${ }^{2}$ The University of Sydney, Sydney, Australia.

Published: 23 November 2015

* Correspondence: natalie.crino@health.nsw.gov.au

'Department of Medical Psychology, Westmead Hospital, Sydney, Australia

Full list of author information is available at the end of the article
doi:10.1186/2050-2974-3-S1-063

Cite this article as: Crino and Touyz: Cognitive style in anorexia nervosa: a preliminary investigation. Journal of Eating Disorders 2015 3(Suppl 1): O63.
Submit your next manuscript to BioMed Central and take full advantage of:

- Convenient online submission

- Thorough peer review

- No space constraints or color figure charges

- Immediate publication on acceptance

- Inclusion in PubMed, CAS, Scopus and Google Scholar

- Research which is freely available for redistribution

Submit your manuscript at www.biomedcentral.com/submit
() Biomed Central
C Biomed Central

C 2015 Crino and Touyz This is an Open Access article distributed under the terms of the Creative Commons Attribution License (http://creativecommons.org/licenses/by/4.0), which permits unrestricted use, distribution, and reproduction in any medium, provided the original work is properly cited. The Creative Commons Public Domain Dedication waiver (http://creativecommons.org/ publicdomain/zero/1.0/) applies to the data made available in this article, unless otherwise stated. 